\title{
Grundtvig - nyckeln till det danska?
}

\author{
Boganmeldelse av Harry Aronson
}

Grundtvig - nyckeln till det danska?, Hanne Sanders och Ole Vind (red.), Makadam förlag, Göteborg - Stockholm, 2003. 300 sidor, pris ca $320 \mathrm{SKr}$. Utgiven i samarbete med Centrum för Danmarksstudier vid Lunds universitet.

Den som på 1950-talet i ett svenskt "forsamlingshus" skulle presentera Grundtvig och hans verkningshistoria utgick gärna från P. G. Lindhardts bild av horisontlinjen i den grundtvigska byn: den dominerades av "frikyrkans" torn, folkhögskolans borg och andelsmejeriets skorsten. Detta panorama framstod då som typiskt danskt. Den som satt igång allt detta var Grundtvig. Svallvågor av dessa rörelser kunde igenkännas också i Sverige - mest i form av ett stort antal folkhögskolor spridda över hela landet. Samt i några högt värderade psalmtexter, transponerade till svenska språket.

Ett halvt århundrade senare är bilden av Danmark som det idylliska agrara landet inte så entydig. Vi har fått EU och globalisering. Vi har genom invandringen tvingats finna oss tillrätta med ett framväxande multikulturellt samhälle, både i Danmark och Sverige. Det är närmast självklart att frågor om identitet är uppstått i denna omvandlingsprocess.

För en svensk betraktare är det påfallande så många initiativ som tagits i Danmark de senaste årtiondena för att beskriva, vidmakthålla och förstärka dansk identitetskänsla. Ett monumentalt verk är Dansk identitetshistorie i 4 delar på ca 2500 sidor, 1991-92. Där spelas teman upp som "Fædreland og Modersmål", "Et yndigt land", "Folkets Danmark" samt "Danmark og Europa" igenom. Här följer det officiella Danmark Grondtvigs uppmaning till danskarna att "gaae i sig selv" för att förstå sin egenart. Ett tiotal forskare friställdes för detta arbete i slutet av 1980-talet och verksamheten sponserades av universitet och folketing. I samband därmed utgavs också en antologi med texter från Saxo till Rifbjerg, "Til belysning af danskens selvforståelse". En rad andra böcker spinner på temat danskhet och identitet.

Stor uppmärksamhet har i Sverige förslagen att skapa en dansk "kulturkod" fått - tanken att varje skolelev/medborgare bör ha kännedom om det identitetsbärande kulturarvet. Klassiska litterära författare/verk listas som omistliga kulturförmedlare ... Också detta projekt får sin särskilda tyngd genom att vara offentligt sanktionerat. Någon sådan samling kring det nationella finns det sannolikt ingen enighet om i Sverige. Senast något liknande skedde var förmodligen vid andra världskriget då ett antal "stamsånger" för skolan fastställdes 
som oumbärliga för gemenskapskänslan.

För att förstå detta typiskt danska är det nödvändigt att förstå vilken betydelse Grundtvig har haft och har i Danmark. I Sverige har det alltsedan hans livstid funnits ett intresse och en förundran inför hans gestalt. I många folkhögskolor finner man hans porträtt på väggen. Det finns efterhand en stor svenskproducerad litteratur om hans betydelse. Det kan vara folkbildningslitteratur eller doktorsavhandlingar eller översättningar, framförallt av hans psalmer. Det kan ha varit fascinationen inför en annorlunda kristendomstolkning eller livssyn som inspirerat.

På senare tid finns också en annan, till synes trivial, anledning: Öresundsbron! I samband med brons tillkomst uppstod förhoppningar om ökad kommunikation, handel och integration och däri ingick också mera omfattande kulturkommunikation. Som led i detta skapades 1998 vid Lunds universitet "Centrum för Danmarksstudier", efter beslut av universitetets styrelse.

Det presenterar sig som en nätverksorganisation för forskare vid Lunds universitet med intresse för Danmark. Centrum vill "skärpa fokus på det danska, som det kan se ut från en svensk horisont och uppmuntra till vetenskapliga jämförelser mellan de två länderna". Arbetsformer är konferenser, litteraturutgivning och rekrytering av forskare.

Utöver denna grannvänliga och förstående attityd markeras i målskrivningen att det självklara i den danska självförståelsen ska "problematiseras" - alltså en kritisk approach. Man har demonstrerat detta program med konferenser om Grundtvig och Kierkegaard. Liksom Grundtvigkonferensen har den senare resulterat i en bok: Tänkarens mångfald. Nutida perspektiv på Sören Kierkegaard, 328 sidor, 2005.

Men det var alltså Grundtvig som kom först, när det gällde att visa, vad eller vem som kan var nyckeln till dansk identitetskänsla. Boken, som utgivits av Hanne Sanders och Ole Vind, består av 9 större artiklar, 5 på danska och 4 på svenska. Boken börjar med en orienterande artikel av Ole Vind: "Grundtvig og det danske med sideblik til Sverige". Det finns också encyklopediskt stoff, bibliografiska upplysningar samt illustrationer. Dessa grundläggande inslag, jämte en sammanfattande inledning, gör boken läsbar också för den som inte tidigare orienterat sig i Grundtvigforskningen. I övrigt måste boken betecknas som en kvalificerad redovisning av forskning och diskussion om Grundtvig och den grundtvigske traditionen, inte helt lättillgänglig för en oinformerad svensk läsare. Artiklarna följs av översättningar till engelska.

Etnologen Tine Damsholt och filosofen Ole Vind behandlar Grundtvigs egenart och hållning i 1800-talets politiska och kulturella skeende. Hur förstå hans upplysningsidéer? Var Grundtvigs demokra- 
tiföreställning en annan än vår? Folkkyrkobegreppet analyseras av Urban Claesson, svensk kyrkohistoriker. Yvonne Maria Werner tar upp frågan om det utifrån Grundtvigs kyrkosyn skapades en bättre grogrund för katolicism än som var fallet i det lutheraniserade Sverige. Bosse Bergstedt, som 1988 disputerat på Grundtvig i ämnet pedagogik, preciserar "den grundtvigske livsoplysning" gentemot det svenska begreppet "bildning", ett centralt begrepp i svensk folkrörelsehistoria och självförståelse.

Ett återkommande drag i Grundtvigforskningen har varit jämförelse med någon annan personlighet för att få relief åt honom. Idéhistorikern Ola Fransson, också han en svensk som blivit doktor på danskt stoff, Harald Höffding, diskuterar Höffdings förhållande till grundtvigianismen.

En kontroversiell fråga i Grundtvigdebatten från 1900-talet och framåt har varit vari Grundtvigs livsproblem egentligen bestod och hur han till sist bestämde förhållandet mellan mänskligt och kristet. Kim Arne Pedersen ger en utförlig och välavvägd redogörelse för dessa problemställningar i sitt 30 sidor omfattande bidrag med titeln "Den theologiske Grundtvigforskning siden anden verdenskrig".

Efterhand har studiet av Grundtvig som teolog och kyrkoman blivit så omfattande och kontroversiellt, att det för en nybörjare är ett mycket omfattande företag att enbart orientera sig i litteraturen för att hitta utgångspunkter för egna analyser. Pedersens genomgång och avvägningar är därför en välkommen hjälp. Lätt kan man följa Pedersen i spåren, gå på djupet i de författarskap han analyserar - och kanske positionera sig och pröva vad som ytterligare kan eller bör sägas om Grundtvig som teolog.

I bidraget från Uffe Jonas - 56 sidor - får vi en omlokalisering av begreppen folklighet och upplysning, "plusord" hittills. Jonas söker efter Grundtvigs relevans för nutiden då globalisering slagit ut nationalistiska ideer och fragmentalisering präglar universitetsmiljön. Artikeln är lätt polemisk. Den riktar sig t. ex. mot den årtalsfixering som präglat Grundtvigförståelsen under andra delen av 1900-talet. Han lyckas därmed på ett fascinerande sätt göra rättviseråt "hela Grundtvig". Titeln är "Poetisk videnskab. Grundtvigs universitetsdrøm som kosmopolitisk dannelsesprojekt".

Ett djärvt grepp är att sammanställa likheter med den franske filosofen Michel Foucault (1926-84). Denne, som vistades i Uppsala 1955-58, hade veterligen dock ingenting med Grundtvig att göra, men det är känt att han under Uppsalatiden proklamerade människans död. Olikheter torde sålunda vara lätta att finna, men Jonas hittar paralleller som gör ett möte dememellan meningsfullt.

Författarens ambition är ingenting mindre än att "udvide og forny vores syn på Grundtvig". Ett inslag i denna riktning är att påpeka den betydelse som Johannesevangeliets logostanke betyder som ferment $\mathrm{i}$ 
Grundtvigs skapelsesyn och ordsymbolik. Genom en rad citat från Danne-Virke-tiden, men även från senare tid, kan Jonas visa upp en Grundtvig som inte är bara nationell utan universell, kosmisk och även eskatologisk. Intuitivt känner man att vi med denna perspektivutvidgning får en gestalt att framträda som är sammanhängande och konsekvent utifrån sina förutsättningar. Kanske också relevant för vår tid och dess perspektivfattiga upplysningsprojekt i skola och universitet.

En berättelse om Grundtvigs roller i nutidens politiska spel ges av Hans Hauge: "Nynationalismen og markedets metafysik - Søren Krarup og Ebbe Kløvedal Reich som moderne grundtvigianere". Därmed är vi framme vid den betydelse Grundtvig tilldelas i den ideologiska kampen idag. För en svensk blir det en lättsam revy över dagspolitiken med Dansk Folkeparti - utan motsvarighet i Sverige och gårdagens intresse för Marx. Krarup presenteras som folketingsman för det danskvänliga partiet. Reich är känd för en fantasieggande folkbok om Grundtvig, för att vara EU-motståndare och politisk aktivist. Båda är angelägna om en revitalisering av Grundtvig, som enligt Hauge numera inte alls läses, men väl sjunges. Här möter vi också ännu en jämförelse av typen "Grundtvig och ...", nämligen Tolkien. I sammanhänget får man också den intressanta upplysningen att mellannamnet "Kløvedal" är inspirerat av Tolkien. Vi vet ju att Tolkien (och C. S. Lewis) öste ur samma historiska källor ...

Så nog gör sig Grundtvig påmind i nutiden. Ibland uttrycks det lite syrligt så att Grundtvig ska "räddas" genom att inkorporeras i nya sammanhang, som kanske behöver argument eller auktoritet: sekulariseringen ska ges legitimitet, marxismen ges ett mänskligt ansikte, hans tänkande visas upp i ett nutida, respektabelt sällskap .., man kunde också vända på formuleringen att det är Grundtvig som är räddaren.

Danskar och svenskar förstår varandra om vi talar tydligt, vi har ju i grunden samma språk. Det är lovvärt att det har skapats en institution som "Centrum" för att främja en djupare förståelse. Centrum för Danmarksstudier preciserar, som nämnts, också sin ambition att "problematisera" danskens självförståelse. Ska det betyda att svenskar kan förstå danskar bättre än de förstår sig själva? En sådan ambition kan tyckas alltför kaxig. Å andra sidan kanske en analys av det danska som sker på svensk mark i starten vara befriad från bindningar och lojaliteter som styr i hemlandet. Det förhärskande positivistiska forskningsklimatet i Sverige - att bara se till det som faktiskt föreligger - kan kanske ge en "cool" utgångspunkt, utan given dansk förförståelse. Med risk att det blir torftigt och utan det levande ordets kraft ...

Det är ett bekant yttrande vid Grundtvigs död - att det inte lystes frid utan strid. Strid har det varit och kommer nog att så förbli. Det tyder ju på att Grundtvig är en viktig nyckel för att få tillgång till de 
rum där Danmarks själ manifesterar sig.

Hanne Sanders, föreståndare för Centrum för Danmarksstudier, avslutar - med anspelning just på kontroverserna - sin sammanfattning av boken med frågan: "Findes der nogen svensker, som kan sætte sindene i kog 130 år efter sin død?”

Frågan är väl retorisk och några svar ska inte försökas här. Kunde man hitta någon, vore det kanske skäl till att grunda ett centrum för Sverigestudier i Danmark, en tanke som lanserades när man startade det danska i Lund. 